\title{
On the Question of Erudition in a Modern Knowledge Society
}

\author{
Slavomír Gálik ${ }^{1}$, Sabína Gáliková Tolnaiová ${ }^{2}$ \\ ${ }^{1}$ Department of Mass Media Communication, Faculty of Mass Media Communication, University of Ss. Cyril and Methodius in \\ Trnava, J. Herdu 2, 91701 Trnava, Slovakia \\ ${ }^{2}$ Department of General and Applied Ethics, Faculty of Arts, Constantine the Philosopher University in Nitra, Hodžova 1, 94901 \\ Nitra, Slovakia \\ s_galik@yahoo.com, sgalikovatolnaiova@ukf.sk
}

\begin{abstract}
The authors speak in this paper about some of the risks that come with education process in the so-called knowledge society, influenced by a rapid development of digital technologies, especially the Internet. The Internet has changed access to information and way of usage of information paradigmatically, introducing thus some changes in education process. The authors speak about 6 risks that a knowledge-based society encounters: reducing knowledge to isolated and expressible blocks of knowledge, outcome, weakening in logical and linear thinking, reduction of awareness of the past and future and acceleration in the information flow with cumulation of information. The authors state that elimination of these risks requires higher degrees of knowledge, such as understanding that relates to education, and wisdom. Wisdom together with education should then, according to the authors, be the most important "competences" in a knowledge society.
\end{abstract}

Index Terms - information, erudition, education, wisdom, linear and net-like linking of information

\section{Introduction}

With development of electronic media and later also digital media in the second half of $20^{\text {th }}$ century, we start to recognise the term of information society and later on, also knowledge society, which became the key term that describes changes in advanced societies that changed from industrial to post-industrial - information or knowledge society. These changes were brought by was expansion of computers and especially the Internet.

In the mid 90s the terms of information and knowledge society became dominant terms and strategies for economy and society development. Conceptions of information or knowledge society, which promised unlimited economic growth and prosperity, were implemented in political and economic programmes of the EU as well as the USA.

In March 2000, top representatives of governments and countries of the EU met in Lisbon to negotiate the so-called Lisbon Strategy. They agreed on an ambitious goal: to make the EU, by the end of 2010, the most competitive and most dynamic knowledge-oriented economy in the world, capable of sustainable growth, with more job vacancies and greater social cohesion. In 2005 however, this strategy had to be revised, as it was found unrealistic. This indicates that the EU leaders wrongly employed stereotype and formal approach, ideologization of information (knowledge) society as the guaranteed cure-all for the entire social and especially economic problems. In the background of his fiasco, there are also more important causes that manifest poor understanding of the fundamental issues of information and knowledge society.

P. Zajac-Vanka comments this: "It seems that knowledge society is purely a matter of information technologies and pedagogy, total number of universities and access to computers in schools. Eventually, new and innovative scientific and research projects are looked for, however this is merely technical resources of knowledge society. We desperately miss the "extension," philosophy and principles that a knowledge society employs. You will not learn why a knowledge society is needed for economy and mankind as such and what basic principles there are for its function." [1] These words of Zajac-Vanka, who specialises in knowledge society, are extremely worrying, for if we do not understand basic terms, then we cannot apply them correctly in real life. This means that understanding the basic issues in information and knowledge society should also be the key to understanding the actual problems in education process. Along with this, we want to identify further risks that are present education process, risks that are connected to in knowledge society, digitalisation or "Internetization" of the society. Basing on identification of these risks, a strategy or counter-action will then be hinted to improve the present situation in modern education system.

\section{Definition of Basic Terms}

Understanding information and knowledge, mutual connections and hierarchy that is here, should be the starting point to understanding present issues in education. However, understanding of the basic terms such as information and knowledge is required here. The road to understanding leads through semiotic rules that are used here- generating of meanings in the grid of positions and oppositions [2]. In our case, we need to correlate information, knowledge and data and consequently define differences between them.

The basic unit is represented by data, which is not information in the real sense of the word, since it only exists in the computer and stands aside semiotic designation. J. Cejpek also says it is necessary to distinguish between information and data: "In this respect, computers are not machines to process information, but process data. We may only speak about information when the receiver is a human being, with his 
consciousness - when he starts to perceive text, image or sound output of the computer or printer. " [3].

"Information" enclosed in computer software exist as if "for itself alone", so we call it data. Data that gets transposed into human symbols in order to enter human sense-based world can then be called information. Information starts to be information when it becomes a part of human understanding and communication. Cejpek however notices that information is not knowledge yet: "Thus mere information is not knowledge, it only creates basic condition for knowledge " [3]. He refers to philosopher J. Patočka, who stated: "the concept of information cannot possibly explain the concept of understanding and knowledge. ... " [3]. Information is still relatively atomised, object-bound, fragmented and therefore countable and disarranged. Knowledge however is a higher level that arranges, synthesizes information into meaningful units. M. Růžička for example understands knowledge (information quality in his approach) as information that reorganizes and changes our experience, knowledge horizon and enters into co-existence of communicating entities [4].

Knowledge alone, cross-referred to just itself, is not enough since it could slip into "atomised models," similarly to information. Individual bits of knowledge therefore need to join each other, synthesize, which is represented by various levels of education. Education system is designed to help us manage certain sort of knowledge. M. Potůček identifies this knowledge-exceeding level as understanding: "Understanding as a further level of knowledge does not only offer an answer for the question of how, but also the question of why. Knowledge cannot be "memorised" or "tried out" and to understand means to comprehend the principles. People who understand can, basing on reasoning (and not just experiment) synthesize available information and knowledge and thus create new knowledge" [5]. We would add that without education, or certain kind of education, we could neither understand nor handle knowledge. The fifth, most advanced degree of knowledge is, according to Potůček, in wisdom: "Wisdom then represents the greatest degree of knowledge. It includes understanding of the general relations between various, even very remote occurrences, knowledge of gaining understanding and experience-proven system of values" [5]. Wisdom then is the total of theory and practice, into which we can add the complex experience of man with value system and ethical actions.

A knowledge society should not only be about atomised knowledge and its economisation, but also understanding (education) and especially wisdom. Reaching the state of being wise should be the goal of a knowledge (understanding) society.

\section{Further Risks in a Knowledge Society}

$1^{\text {st }}$ risk in a knowledge society - reduction of knowledge to mere atomised information without further relation to erudition and wisdom.

To further explain terms such as information or knowledge, we have to state that these cannot be expressed, objectivised or quantified exhaustively. A part of the meaning, due to its context-based nature of generation, is always in the dim region of the consciousness (or unconsciousness). This inexpressible knowledge is also known as tacit knowledge. F. Murgaš characterises tacit knowledge as "non-verbalized and usually unconscious. Here, verbalising is difficult, intuition ability and creativity is visible in communicating tacit knowledge" [6]. A wise and educated man commands a great deal of tacit knowledge that manifests indirectly, for example in creativity, virtue of orientation, systematic work with knowledge and similar. Effect of tacit knowledge is obvious in the already mentioned intuition that we can understand as nonmediated and sudden knowledge. Yet, this kind of knowledge usually comes after pre-existing accumulated knowledge and experience. The sudden idea synthesis - new knowledge - is manifestation of the preceding accumulated knowledge that we cannot consciously access. This intuitive knowledge lies in the highest levels of the so-called innovations and is usually identified by new and unexpected way of dealing with a problem. Eliminating of tacit knowledge in a knowledge society, but also economy, then means eliminating intuition and creativity. Therefore the biggest risk in a knowledge society is, we believe, atomisation of knowledge and reduction of knowledge to some kind of expressible correlate.

$2^{\text {nd }}$ risk in a knowledge society - reduction of knowledge to only expressible and useful knowledge.

Critical thinking is often assigned to information or knowledge-based competences [7]. Critical thinking characteristics set high demands on the subject of critical thinking, who needs to free, creative and rationally and argumentatively competent. These criteria can only be met by a wise and educated person, as we have already mentioned. In this case however, intellect is not the only requirement, but comes along a whole complex of mental, psychic and physical dispositions with such a value system that puts the good to the highest of positions.

Basing on this perspective, we see that the next risk in a knowledge society is in reduction of critical thinking to mere intellectual operations of the brain, without connection to the deeper structure of human being. This approach often generates false conceptions, for example concerning automatic generation of critical and creative thinking.

$3^{\text {rd }}$ risk in a knowledge society - fixation to results rather than conditions of knowing - man as a combination of psychophysical, axiological and moral being.

Birth of information society and then its extension, knowledge society, relates to birth of electronic media, specifically of the Internet in the early 90s. The Internet is a par excellence medium of knowledge society. Yet communication through the Internet witnesses major structural changes in the way of human thinking and consequently in culture. The most visible change is in shifting from linear to net-based connections of information, which we can see as disintegration of "linear code" and which is reflected in the change in thinking and understanding of time. Net-like interconnection of information could also be explained by the 
term rhizomorph (rhizome - botanical term that describes a thread-like structure or roots) that is quite well-established in philosophical discussions about media. This term was first used before the Internet by G. Deleuze and F. Guattari, they described it as follows: "unlike trees or their root structures, a rhizome connects any given point with another any given point, while each of the symbols does not provide a link to other symbols of the same kind; it introduces very different regimes of symbols, even non-symbol states “ [8]. Similarly, U. Eco followed the concept of rhizome and put it aside the previous tree-like (arborescent) thinking. The idea of a tree in, let us say, Middle Ages thinking (arbor porphyriana) represented the order of hierarchy-based and logical thinking from the essence of being to its marginal manifestations [9]. Rhizomatic thinking, on the contrary, is non-systematic, fragmentary, net-like, with no beginning and no end.

U. Eco even claims that rhizome justifies and supports even contradictions, since rhizome creates non-linear loop processes. He says: "to think means advance blindly in the rhizome, follow just assumptions " [9]. The Internet, which is characteristic for its hypertext or let us say rhizomatic interconnection of information, will not support abstract, linear and logical thinking. Desultoriness of thinking will also be supported by dominance of images on the Internet, which also implies entertainment and desultory attitude [10].

$4^{\text {th }}$ risk in a knowledge society - weakening in linear, logical and in-depth thinking.

Along with disintegration of linear thinking comes also disintegration of the idea of linear time. In communication on the Internet, there are no physical footholds that would enable measuring the time. Time becomes present, simultaneous on the Internet. Hypertext non-linear interconnection of information, which has no beginning and no end, also advocates synchrony of time. Such perception and experience of time then affects understanding of culture, which is no longer set on tradition but becomes contemporary by the means of hypertext. P. Rankov says: "in a net, culture spreads only horizontally, simultaneously, merely spatially and time means nothing. ... Information transfer in time is nowadays merely a side-effect of the net-based culture. " [11]. Strengthening of the present can on the other hand lead to denying the past (but also future) with all that the past contains such as tradition, religion, idea of nation and similar. According to M. Bauerlein, who did researches in erudition in American youth, he came to a conclusion that knowledge which somehow incorporates the past is declining year by year, which presents a risk for the future progress in democracy and functioning of the state [12]. This loss of sense of the past and future can mean a great risk for a knowledge society.

$5^{\text {th }}$ risk in a knowledge society - weakening of the connection to the past and future and strengthening of the present.

Communication on the Internet is getting close to the speed of light, so it is almost immediate for a user. High communication speed on the Internet will speed up all our aspects of life, because we use the Internet to learn, communicate, work, shop and do business. The high speed of communication and geometric growth of information on the Internet will cause troubles in processing of information timely. Cumulation of information, as T. H. Eriksen notices, will lead to simplification and imperfections, information noise and fading in the difference between working time and spare time [13]. Eriksen says: "Some of the consequences of its usage can already be seen now: it shortens distances and fills the current moment with information. Similarly to cars and jet planes, new information technologies lead to acceleration and require further acceleration until the time is close to zero " [13]. Possibility for acceleration of information flow and its accumulation is not unlimited, because there are certain biological and psychological limitations in human, therefore it can mean a great danger for knowledge society.

$6^{\text {th }}$ risk in a knowledge society - acceleration and cumulation in information flow.

\section{Conclusion}

In this paper we analysed the causes of failure of a knowledge society, we also formulated six risks in a knowledge society that have a direct effect on level of erudition: reduction of knowledge to just atomised knowledge, reduction of knowledge to just expressible knowledge, reducing knowledge to just results, weakening of the linear, logical and in-depth thinking, weakening of the relation to the past and future, acceleration of the flow of information and cumulation of information.

To realise these risks is a task for those who dedicate themselves to theoretical and especially practical preparation of strategies of development in all aspects of a knowledge society, including erudition aspect [14]. Such consciousness relates to understanding (education) and wisdom, because society will progress only if there are wise and educated people. Wisdom along with erudition should therefore represent the basic "competence" of a knowledge society [15] that will also imply a qualitatively higher level of erudition.

\section{Acknowledgment}

This contribution is a partial outcome of the national grant VEGA 1/0284/14 (name of the project: Cyberspace as a new dimension of man, author: prof. PhDr. Slavomír Gálik, PhD., project span: 2014 - 2016).

\section{References}

[1] P. Zajac-Vanka, "Vedomostná ekonomika - vedomostná spoločnost““ In $<$ http://zajacvanka.zunet.sk/vedomostna-ekonomika-vedomostnaspolocnost/> [online], [2015-02-04].

[2] M. Solík, "Semiotic approach to analysing of advertising" European Journal of Science and Theology, 2014, Vol 10, Suppl. 1, p. 207 - 217.

[3] J. Cejpek, 'Informace, komunikace a myšlení. Úvod do informační vědy“" Praha : Karolinum 2005.

[4] M. Růžička, ”Informace a dobro“" Praha : Ježek 1993.

[5] M. Potůček et all., "Putování českou budoucností“, Praha : Centrum pro sociální a ekonomické strategie, Fakulta sociálních věd UK v Praze, 2003. 
[6] F. Murgaš, "Znalostná ekonomika, tacitné znalosti, spillovers znalosti a ludský kapitál“, RELIK 2011 [online ] [cit. 2014-10-10], p. 1 - 9. In $<$ http://kdem.vse.cz/resources/relik11/sbornik/download/pdf/149Murgas-Frantisek-paper.pdf>

[7] A. Plencner, "Critical Thinking and the Challenges of Internet", Communication Today, Vol. 5, No. 2, November 2014, pp. 4 - 18.

[8] G. Deleuze, F. Guattari, "Tisíc plošin“, Praha : Herrmann a synové 2010.

[9] U. Eco, "Od stromu k labyrintu. Historické studie o znaku a interpretaci“, Praha : Argo, 2012.

[10] H. Pravdová, ”Determinanty kreovania mediálnej kultúry“, Trnava : FMK UCM 2009.

[11] P. Rankov, "Informačná spoločnost' - perspektívy, problémy, paradoxy“, Levice : LCA Publisher Group, 2006.
[12] M. Bauerlein, ”Najhlúpejšia generácia. Ako digitálna éra ohlupuje mladých Američanov a ohrozuje našu budúcnost' alebo: never nikomu pod 30" [The dumbest generation: How the digital age stupefies young Americans and jeopardizes our future (Or, don't trust anyone under 30)], Bratislava : Vydavatel'stvo Spolku slovenských spisovatel'ov 2010.

[13] T. H. Eriksen, ”Tyranie okamžiku“, Brno : Dplněk 2009.

[14] T. Tökölyová, \& A. Modrzejewski, Role of mass media in foreign policy decision-making. European Journal of Transformation Studies, 2013, 1 (2), 37-47.

[15] D. Petranová, L. Burianová, "Potential of Digital Technologies Use in the Formal Pre-Primacy Education" European Journal of Science and Theology, 2014, Vol 10, Suppl. 1, p. 263 - 276. 